\title{
MIASTO JAKO DOBRO WSPÓLNE CZY SUMA PRYWATNYCH WŁASNOŚCl? O POLSKIEJ KWESTII MIEJSKIEJ W KONTEKŚCIE DZIAŁALNOŚCI RUCHÓW MIEJSKICH
}

The City as a Commons or the Sum of Private Property? Polish Urban Question in the Context of Urban Social Movements Activities

\begin{abstract}
The article discusses two ideas of the city in the Polish public discourse: the city as a commons and its antithesis - the city as the sum of private property. In the first part of the article, the author analyses the processes in which both ideas were developed. In the second part of the article the author analyses the role of Polish urban social movements, which are one of the few social actors that discussed the idea of the city as a commons when Polish public discourse was dominated by neoliberal dogmas in which the city was reduced to the sum of private property. In conclusion, according to Victor Turner's concept of social change, the author analyses the impact of the COVID-19 pandemic on the reception of both ideas in Polish public discourse.
\end{abstract}

Keyword: city, urban movements, commons, neoliberalism, COVID-19

\section{Wprowadzenie}

Artykuł poświęcony jest analizie postawy wobec dwóch różnych idei kształtujących polskie polityki miejskie: idei miasta jako dobra wspólnego oraz idei miasta jako sumy prywatnych własności. Problematyka ta z jednej strony uwarunkowana jest specyfiką polskiej kwestii miejskiej kształtowanej w procesie długiego trwania, z drugiej natomiast wpisuje się w jeden z głównych tematów klasycznej socjologii, wyznaczany między innymi koncepcjami Ferdinand Tönnies, opisującego dwa różne modele społeczeństwa: Gemeinschaft i Gesellschaft. Zdaniem niemieckiego socjologa Gemeinschaft (wspólnota) stanowi model charakterystyczny dla społeczeństw 
tradycyjnych, żyjących w ramach silnych wspólnot terytorialnych, a Gesellschaft (stowarzyszenie) to odpowiednik wielkiego miasta ze szczytowego okresu nowoczesności, gdzie stosunki międzyludzkie mają charakter instrumentalny i bezosobo$\mathrm{wy}^{1}$. Na gruncie antropologii podobny model - kontinuum folk-urban - przedstawił Robert Redfield, który na podstawie badań porównawczych różnych form osadnictwa analizował kontrast między ludowością a miastem oraz wpływem miasta na zmiany w tym, co ludowe ${ }^{2}$.

Podobnych koncepcji przedstawiono wiele, a ich recepcja była na tyle silna, że ukształtowało się dość powszechne przekonanie, że (wielko)miejskie Gesellschaft charakteryzują się wyłącznie anonimowością, indywidualizmem i różnorodnością, podczas gdy dominującą cechą tradycyjnych Gemeinschaft jest jednorodność i siła więzi społecznych. Zgodnie z takimi założeniami idea dobra wspólnego mogłaby się rozwijać jedynie w społeczeństwie tradycyjnym, gdyż w zindywidualizowanym i różnorodnym wielkomiejskim środowisku trudno byłoby określić to, co wspólne dla całej społeczności. Miasto jest jednak specyficznym organizmem, w którym cały czas funkcjonują oba typy społeczeństw, tyle tylko, że z uwagi na specyfikę kontekstu raz na pierwszy plan wysuwa się Gesellschaft, innym razem jest to Gemeinschaft. Jeśli odniesiemy się tylko do najnowszej historii, zobaczymy wyraźnie, że dominacja ideologii neoliberalnej w ostatnich dekadach sprzyjała rozwojowi miejskiego $\mathrm{Ge}$ sellschaft. W tym przypadku przestrzeń miejska miała sprzyjać i stymulować rozwój indywidualizmu i przedsiębiorczości, a samo miasto sprowadzane było do roli metaforycznej „firmy”. Współczesny kontekst, wyznaczany duchem nowego urbanizmu, ekonomią współdzielenia i tendencjami do swoistej „reruralizacji” miast, sprzyja natomiast wzmacnianiu Gemeinschaft, w ramach którego miasto nie jest już postrzegane jako przedsiębiorstwo, ale coraz częściej jako dobro wspólne.

Sama idea dobra wspólnego (commons) w kontekście kwestii miejskiej dyskutowana jest od niedawna i jak zauważa Maja Grabkowska: „W ukazującym się od $2007 \mathrm{r}$. czasopiśmie naukowym poświęconym problematyce dóbr wspólnych «International Journal of Commons» znalazło się dotychczas zaledwie kilka artykułów traktujących o miejskich dobrach wspólnych, a ponadto niewiele opublikowanych tekstów dotyczy regionu Europy Środkowej i Wschodniej"’3. Niemniej w ostatnich latach, z uwagi na sprzyjający kontekst, problematyce miejskich dóbr wspólnych poświęca się coraz więcej uwagi ${ }^{4}$. Wciąż brakuje precyzyjnych kryteriów wyznaczających zakres tego pojęcia. Na potrzeby niniejszego artykułu pod pojęciem miejskich dóbr wspólnych

1 F. Tönnies, Wspólnota i stowarzyszenie. Rozprawa o komunizmie i socjalizmie jako empirycznych formach kultury, Państwowe Wydawnictwo Naukowe, Warszawa 1988.

2 U. Hannerz, Odkrywanie miasta. Antropologia obszarów miejskich, Wydawnictwo Uniwersytetu Jagiellońskiego, Kraków 2006, s. 73-81.

3 M. Grabkowska, Przestrzeń miasta postsocjalistycznego jako dobro wspólne. Przegląd koncepcji teoretycznych, „Prace Geograficzne”2017, z. 149, s. 33-53, DOI: 10.4467/20833113PG.17.009.6925.

4 Por. M. Czornik, Miejskość dóbr wspólnych. Refleksje nad adaptowaniem koncepcji Common-Pool Resources, „Rozwój Regionalny i Polityka Regionalna” 2018, nr 43, s. 71-82. 
rozumieć będę trudno odnawialne zasoby miejskie wpływające na jakość życia całej miejskiej wspólnoty, do których zalicza się przede wszystkim: tożsamość lokalną, ład przestrzenny, jakość powierza i zasoby przyrodnicze. Zagadnienia te stanowią centralne pole zainteresowania ruchów miejskich, które - jak będę to udowadniać w artykule - stały się głównym agentem zmiany w odniesieniu do polskich polityk miejskich. Chodzi tu w pierwszej kolejności o przełamywanie silnie utrwalanego dyskursu, w ramach którego miasto sprowadzane było do sumy prywatnych własności, na rzecz postrzegania go w kategoriach dobra wspólnego. Wybuch pandemii COVID-19 oraz jej dotychczasowe skutki sprawiły, iż dyskutowana problematyka nabrała nowego znaczenia i wątek ten szczegółowo analizować będę w końcowej części artykułu.

\section{Miasto jako dobro wspólne czy suma prywatnych własności?}

Jednym ze skutków transformacji systemowej '89 roku było to, że przestrzenie polskich miasta podlegały intensywnym procesom prywatyzacji. W specyficznym kontekście posttransformacyjnym miasto zostało sprowadzone do sumy prywatnych własności. Jeśli jednak spojrzymy na polski wzór kulturowy z perspektywy długiego trwania $^{5}$, to takie działania niespecjalnie dziwią. Słabość rodzimego mieszczaństwa i kultury miejskiej oraz silne narracje antyurbanistyczne nie tworzyły podstaw do rozwoju miejskości i miejskiego stylu życia. Dodatkowo jednym ze skutków procesów ruralizacji miast w okresie PRL-u było dominujące przekonanie, że przestrzenie publiczne i miejsca wspólne są niczyje i niepotrzebne. Biorąc pod uwagę powyższe czynniki, powszechne w latach 90. tendencje do prywatyzacji miasta wydają się łatwe do zrozumienia. Trudno jednak zrozumieć to, że po akcesji Polski do Unii Europejskiej procesy te zamiast zanikać, jeszcze bardziej przyspieszyły. Wydawać by się mogło, że wraz ze wstąpieniem do UE postępować będzie intensywny proces europeizacji, zwłaszcza w aspekcie miejskości. Tak się nie stało, a jedną z przyczyn tego stanu rzeczy był stosunek do idei miasta jako dobra wspólnego, którą w tym przypadku można traktować jako probierz europeizacji polskich miast.

W tradycji europejskiej idea miasta jako dobra wspólnego jest głęboko zakorzeniona. Już w antycznej Grecji jeden z filarów, na których uformowała się cywilizacja europejska, czyli miasto (polis), traktowano jako najważniejsze dobro wspólne. Paweł Rybicki, analizujący istotę antycznego polis, pisał, że: „W rozumieniu Arystotelesa polis była pełną wspólnotą, która osiąga kres wszechstronnej samowystarczalności. Dla autora Polityki powstaje ona dla umożliwienia życia, istnieje zaś, aby życie dobrze kształtować" . Pomimo upadku świata antycznego pamięć o mieście jako wspólnocie przetrwała przez całe średniowiecze, dzięki czemu stawały się one

5 Szczegółowo procesy te omawiam w książce: P. Kubicki, Wynajdywanie miejskości. Polska kwestia miejska z perspektywy dtugiego trwania, Wydawnictwo Nomos, Kraków 2016.

$6 \quad$ P. Rybicki, Społeczeństwo miejskie, Państwowe Wydawnictwo Naukowe, Warszawa 1972, s. 367. 
„wyspami wolości na morzu feudalnych zależności”. Zdaniem Henryka Samsonowicza ,tylko w Europie powstały miasta stanowiące wspólnotę ludzi decydujących w większym czy mniejszym stopniu o swych działaniach, miasta samorządne. Granice Europy - jej cywilizacji - sięgają tam, gdzie wdrażane były idee samorządności. Miasta powstały przed tysiącami lat. Ale miasta samorządowe narodziły się w średniowieczu"7. Z kolei Max Weber, charakteryzując najistotniejsze cechy miasta Zachodu, pisał między innymi, że „w pełni rozwinięte miasto antyczne i średniowieczne było przede wszystkim ukonstytuowanym jako zbratanie lub tak interpretowanym związkiem"». Na skutek tych zależności kształtowanych w procesie długiego trwania wielu autorów podkreślało nierozerwalny związek cywilizacji europejskiej z miejskością. Przykładowo Stanisław Grzybowski pisał wręcz, że: „Cywilizacja Europy jest cywilizacją miast. Prawdziwe granice Europy są tam, gdzie sięgają wpływy miejskiej kultury"9.

Miasto europejskie stanowiło wspólnotę współzależnych od siebie ludzi, jednocześnie w myśl maksymy Stadtluft macht frei (powietrze miejskie czyni wolnym) było ono także przestrzenią wolności pozwalającą na rozwój indywidualizmu i innowacyjności. Te specyficzne właściwości miasta europejskiego na przykładzie Amsterdamu opisywał Russell Shorto:

istniała tam ciągłą gra między społeczeństwem a jednostką. Pragnienie wspólnego ponoszenia ryzyka doprowadziło do powstania pierwszej międzynarodowej korporacji i pierwszej giełdy papierów wartościowych. Potrzeba współpracy, silnie odczuwana przez mieszkańców Amsterdamu zaowocowała bezprecedensowym sukcesem niektórych z nich. A ponieważ na tym jednostkowym sukcesie korzystało całe społeczeństwo, stworzyło ono nowy rodzaj przestrzeni miejskiej, która z kolei sprzyjała współpracy jako metodzie dalszego zwiększania dobrobytu jednostek ${ }^{10}$.

Idea miasta jako wspólnoty, wpisana w europejskie dziedzictwo w procesie długiego trwania, została poddana ciężkiej próbie w zetknięciu się z rozwijającą się do lat 70. ubiegłego wieku ideologią neoliberalną. Andrzej Szahaj, wyjaśniając istotę neoliberalizmu, pisał, że jest to:

doktryna polityczna i ideologiczna, która doprowadziła do skrajności, typowy dla liberalizmu i w wersji umiarkowanej zawsze wart ochrony, indywidualizm, czyniący realizację egoistycznie pojmowanego interesu jednostki jedynym kryterium dobrego życia. $\mathrm{W}$ ten sposób z pola widzenia zniknęła jakkolwiek rozumiana wspólnota, której dobro nie było czystą fikcją jeszcze dla klasycznych liberałów, jak Adam Smith czy John Stuart Mill, nie wspominając już o tzw. Nowych Liberałach brytyjskich, którzy pod koniec XIX w. szukali formuły liberalizmu

7 H. Samsonowicz, Życie miasta średniowiecznego, Wydawnictwo Poznańskie, Poznań 2001.

8 M. Weber, Gospodarka i społeczeństwo. Zarys socjologii rozumiejacej, przeł. D. Lachowska, Wydawnictwo Naukowe PWN, Warszawa 2002, s. 927.

9 S. Grzybowski, Trzynaście miast, czyli antymonie kultury europejskiej, Zakład Narodowy im. Ossolińskich, Wrocław-Warszawa-Kraków 2000, s. 5.

10 R. Shorto, Amsterdam. Historia najbardziej liberalnego miasta na świecie, przeł. W. Jeżewski, Wydawnictwo Magnum, Warszawa 2013, s. 109. 
pozwalającej harmonizować interes jednostek z interesem wspólnoty. Wedle ich podejścia szczęście jednostki jest możliwe jedynie wtedy, gdy i inni są szczęśliwi, w tym sensie nie można być szczęśliwym w nieszczęśliwej wspólnocie. Ta szlachetna tradycja liberalizmu została całkowicie porzucona przez neoliberalizm w wydaniu laureata Nagrody Nobla z 1976 r. - Miltona Friedmana, jego głównego proroka i propagatora ${ }^{11}$.

Tak rozumiana ideologia neoliberalna stała w sprzeczności z istotą miasta europejskiego kształtowaną w procesie długiego trwania, łączącą w dialektycznej zależności kolektywizm z indywidualizmem. Z tego powodu procesy odrodzenia miejskiego, które rozpoczynały się w tym czasie, stosunkowo szybko ujawniły swoje drugie, janusowe oblicze.

\section{W poszukiwaniu lekarstwa na kryzys miejski. Odrodzenie miejskie i neoliberalizm}

Kryzys miejski lat 70. i 80. był następstwem wielu czynników, przy czym z punktu widzenia dalszych rozważań dwa z nich wydają się szczególnie ważne: demontaż państwa dobrobytu oraz deindustrializacja miast. Claus Offe zwracał uwagę, że w zachodnioeuropejskiej polityce lat powojennych, aż do początku lat 70., kluczowymi kwestiami były zagadnienia wzrostu gospodarczego, dystrybucji i bezpieczeństwa. Społeczny, ekonomiczny i polityczny porządek został zbudowany pod koniec lat 40 . i na początku 50. wokół szerokiego liberalno-demokratycznego konsensusu - koncepcji państwa dobrobytu, która nie była podważana przez jakąkolwiek znaczącą siłę polityczną ani z prawa, ani z lewa ${ }^{12}$. Ten konsensus się jednak skoczył i jak pisał Andrzej Bukowski:

Od lat siedemdziesiątych ubiegłego wieku badacze notują nieustanny wzrost krytycyzmu i sceptycyzmu obywateli wobec polityki i systemów politycznych zachodnich demokracji. Niezadowolenie z funkcjonowania administracji różnych szczebli związane jest z głębokimi przemianami w kulturze politycznej społeczeństw zachodnich, zachodzących równolegle do przeobrażeń gospodarczych i społecznych. Kolejne fale kryzysu ekonomicznego na Zachodzie, będący ich konsekwencją ostateczny upadek formuły państwa bezpieczeństwa socjalnego, a także skandale polityczne ostatnich lat spowodowały, że obywatele stali się bardzie nieufni wobec politycznego establishmentu, mniej chętni do uczestnictwa w tradycyjnych zrytualizowanych formach życia politycznego (wybory, referenda, partie polityczne), za to bardziej skłonni do działania w formułach niesformalizowanych, alternatywnych wobec oficjalnych niezależnych (ruchy polityczne, organizacje pozarządowe, żywiołowe protesty, organizowane ad hoc) ${ }^{13}$.

11 A. Szahaj, Neoliberalizm, turbokapitalizm, kryzys, Instytut Wydawniczy Książka i Prasa, Warszawa 2017, s. 89-90.

12 C. Offe, Nowe ruchy społeczne. Przekraczanie granic polityki instytucjonalnej, w: P. Sztompka, M. Kucia (red.), Socjologia. Lektury, Wydawnictwo Znak, Kraków 2006, s. 219-220.

13 A. Bukowski, Wspólzarządzanie europejskim miastem - powrót do demokratycznych korzeni? Wnioski z realizacji programu badawczego Demos, w: K. Gorlach, P. Mooney (red.), Dynamika 
Opisywane niezadowolenie stworzyło dogodne struktury możliwości dla rozwoju ruchów społecznych, które w specyficznym kontekście coraz częściej przybierały formę ruchów miejskich.

Wraz z demontażem modelu państwa dobrobytu rozpoczął się też intensywny proces deindustrializacji miast zachodniej Europy. Skalę tego zjawiska można przedstawić na przykładzie baskijskiego Bilbao, miasta, które z czasem stało się symbolem miejskiego odrodzenia. Joanna Orzechowska-Wacławska, analizując procesy zachodzące w tym mieście, pisała, że:

w Kraju Basków proces deindustrializacji przebiegał bardzo gwałtownie. Między 1975 a 1985 rokiem zatrudnienie spadło o 24\%, co odpowiadało cięciom ok. 94700 etatów. Jeśli w 1973 roku poziom bezrobocia był na poziomie 3\%, w 1986 wynosił już 22,9\%. Pogorszeniu uległa nie tylko socjoekonomiczna sytuacja ludności bilbaońskiej, ale też szeroko rozumiana jakość życia w mieście: zarówno przemysł, jak i port, który coraz bardziej przesuwał się w kierunku ujścia rzeki, pozostawiły po sobie wiele zniszczonych i zaniedbanych terenów. Z wizytówki nowoczesności i postępu Bilbao zamieniało się w latach 70. i 80. w upadający ośrodek poprzemysłowy ${ }^{14}$.

Wiele europejskich miast doświadczyło podobnych skutków deindustrializacji, co sprawiało, że w latach 70. i 80. znalazły się one w głębokim kryzysie, i to nie tylko gospodarczym, ale również społecznym i kulturowym (kryzys tożsamości).

Lekarstwem na kryzys miejski miał się okazać nowy, postfordowskiej model gospodarki. W ramach tego modelu rozwijała się tzw. gospodarka symboliczna ${ }^{15}$, opierająca się głównie na konsumpcji szeroko rozumianej kultury miejskiej, tworzonej przez: galerie, muzea, teatry, kluby, restauracje itp., oraz na turystyce miejskiej. Szczególną jednak wagę przywiązywano do rozwoju przemysłów kreatywnych, co wybrzmiało w głośnych koncepcjach, takich jak między innymi „miasta kreatywne”16 czy „klasa kreatywna" ${ }^{17}$. Przestawienie miast na nowe tory rozwoju gospodarczego początkowo zaczęło przynosić spektakularne efekty i pobudzać procesy świadczące o odradzaniu się miast. Pod koniec XX wieku zaczęto już pisać o miejskim odrodzeniu, zdaniem Andrzeja Majera będącym

metaforyczną nazwą następnego etapu i interpretacją procesu, który w istocie pogłębia jakościową odnowę, dzięki czemu miasta w różnym tempie odzyskują atrakcyjność. Świadczą o tym co najmniej dwie zauważalne tendencje. Pierwszą jest odradzanie się w znaczeniu

życia spotecznego. Wspótczesne koncepcje ruchów społecznych, Wydawnictwo Naukowe Scholar, Warszawa 2005, s. 178.

14 J. Orzechowska-Wacławska, Baskijskie polityki miejskie. Konstruowanie nowej symboliki i nowego oblicza Bilbao, „Politeja. Pismo Wydziału Studiów Międzynarodowych i Politycznych UJ” 2014, nr 27, s. 214.

15 S. Zukin, The Cultures of Cities, Blackwell, Oxford 1995.

16 Ch. Landry, Kreatywne miasto. Zestaw narzędzi dla miejskich innowatorów, Narodowe Centrum Kultury, Warszawa 2014.

17 R. Florida, Narodziny klasy kreatywnej, przeł. T. Krzyżanowski, M. Penkala, Narodowe Centrum Kultury, Warszawa 2010. 
demograficznym i ekonomicznym całych aglomeracji, które przedtem systematycznie traciły populację i bazę gospodarczą, drugą - wyraźne ożywanie (to znaczy pojawianie się wielu pozytywnych zmian) centralnych dzielnic miast ${ }^{18}$.

W początkach nowego milenium optymizm co do rozwoju miast był już na tyle silny, że dość powszechnie pisano o trumfie miast ${ }^{19}$, przewidując, że to właśnie one w nowym stuleciu będą zastępować coraz mniej funkcjonalne państwa narodowe ${ }^{20}$. Jako przykład tak rozumianych procesów najczęściej wskazywano na tzw. ,efekt Bilbao", czyli spektakularny przykład miejskiego odrodzenia nieformalnej stolicy Kraju Basków dzięki rozwojowi kultury miejskiej, czego symbolem stało się otwarte w tym mieście w 1997 roku Muzeum Guggenheima. Przy czym, jak podkreślała cytowana już wcześniej Orzechowska-Wacławska, pozytywnego wpływu muzeum na ekonomię regionu nie należy jednak przeceniać. Biorąc pod uwagę wielkość PKB Kraju Basków (35,4 mld euro w 1998 r. i 65,1 mld euro w 2010 r.), dodatkowy dochód powstały w wyniku działalności muzeum stanowi relatywnie niewielką kontrybucję rzędu 0,35\% (rocznie) ${ }^{21}$. Sukces „efektu Bilbao” sprawiał, że starano się go powtórzyć w innych miastach. Problem w tym, że najczęściej wybierano drogę na skróty i zamiast długofalowej oddolnej rewitalizacji inwestowano znaczne środki w spektakularne i bardzo drogie budynki, które zyski przynosiły inwestorom i projektantom, ich koszty natomiast ponosiła wspólnota lokalna.

\section{Przedawkowanie lekarstwa. Gentryfikacja}

Neoliberalne polityki miejskie, które w początkowej fazie niewątpliwie przyczyniły się do odrodzenia miejskiego, z czasem okazały się poważnym zagrożeniem dla miejskiej wspólnoty. Im bardziej implementowano taki model rozwoju, tym częściej zamiast miejskiego odrodzenia mieliśmy do czynienia z gentryfikacją. Mimo że samo zjawisko gentryfikacji zostało opisane już w latach 60. ubiegłego wieku ${ }^{22}$, dopiero w ostatnich dekadach zaczęło być postrzegane jako realny problem utrudniający zrównoważony rozwój miast. Początkowo procesami gentryfikacji dotknięci byli gorzej sytuowani mieszkańcy miast, wypierani ze swoich dzielnic przez ,szlachetnych”, czyli wszystkich tych, którzy są dobrymi konsumentami gospodarki symbolicznej i przemysłów kreatywnych. Z czasem jednak logika neoliberalnej polityki miejskiej sprawiła, że także owi „szlachetni” zaczęli być wypychani z dzielnic, które wcześniej sami gentryfikowali. Mechanizm taki, na przykładzie cyklu życia

18 A. Majer, Odrodzenie miast, Wydawnictwo Naukowe Scholar, Wydawnictwo Uniwersytetu Łódzkiego, Łódź-Warszawa 2014, s. 137.

19 E. Glaeser, Triumph of the City: How Urban Space Make Us Human, Pan Books, London 2012.

20 B. Barber, Gdyby burmistrzowie rządzili światem, przeł. H. Jankowska, K. Makaruk, Wydawnictwo Muza, Warszawa 2014.

21 J. Orzechowska-Wacławska, op. cit., s. 222-223.

22 R. Glass, London: Aspects of Change, MacGibbon \& Kee, London 1964. 
dzielnicy artystycznej, analizowali Monika Murzyn-Kupisz i Jarosław Działek, pisząc, że dzielnice te:

powstają mniej lub bardziej spontanicznie, przyciągają początkowo pionierskich artystów, rozwijają się i zyskują na popularności wśród twórców. W miarę jak upowszechnia się alternatywny wizerunek dzielnicy, na jej teren zaczynają napływać bardziej konserwatywni artyści oraz mieszkańcy innych dzielnic, spragnieni możliwości doświadczania wyjątkowości kwartału. W konsekwencji na popularności dzielnic artystycznych w okresie szczytu ich rozwoju rzadko korzystają czy to artystyczni pionierzy ich przekształceń, czy to ich dotychczasowi mieszkańcy. Pomimo prób przeciwstawiania się silniejszym graczom na rynku nieruchomości, są stopniowo wypierani z dzielnicy przez nowych, niezwiązanych ze światem sztuki mieszkańców, deweloperów oraz czasowych użytkowników dzielnicy, takich jak turyści oraz imprezowicze z innych dzielnic ${ }^{23}$.

W efekcie, jak pisali autorzy w innym miejscu, dzielnice takie wspierają raczej rozwój „kotłów neoliberałów” niż „tygli kreatywności”24. Niemal wszystkie dzielnice artystyczne w miastach europejskich przechodziły podobne procesy. W polskim przypadku symbolem tych procesów stał się krakowski Kazimierz, którego odrodzenie w dużej mierze dokonywało się dzięki osiedlającym się tam artystom, a który obecnie bardziej przypomina rozrywkowy park tematyczny dla turystów niż dzielnicę kreatywną.

Taki model rozwoju miast był coraz bardziej kontestowany przez rosnące w siłę ruchy miejskie. Mimo iż miasto od dawna było sceną mobilizacji ruchów społecznych, ruchy miejskie są zjawiskiem stosunkowo nowym. Sam termin pojawił się po raz pierwszy dopiero w początkach lat 70. na kartach Kwestii miejskiej Manuela Castellsa $^{25}$, natomiast rozwiniętą koncepcję tego zjawiska kataloński socjolog przedstawił w swoich kolejnym pracach w latach $80 .{ }^{26}$ Upraszczając nieco sprawę, można stwierdzić, że ruchy miejskie powstawały w dialektycznym powiązaniu z neoliberalizmem. Im większe triumfy święcił neoliberalny model polityk miejskich, tym więcej mieszkańców miast ponosiło jego konsekwencje, co przekładało się na mobilizację społeczną w ramach ruchów miejskich broniących prawa do miasta. Szczególnego znaczenia w tym kontekście nabrał kryzys z roku 2008 i jego skutki. Badacze pisali wręcz o „,buncie miast”27 czy „miejskim powstaniu” ${ }^{28}$ przeciwko neoliberalnym po-

23 M. Murzyn-Kupisz, J. Działek, Artyści w przestrzeni miejskiej Krakowa i Katowic, Universitas, Kraków 2017, s. 108-114.

24 Ibidem, s. 83.

25 M. Castells Kwestia miejska, przeł. B. Jałowiecki, J. Piątkowski, Państwowe Wydawnictwo Naukowe, Warszawa 1982.

26 M. Castells, The City and the Grassroots: A Cross-cultural Theory of Urban Social Movements, University of California Press, Berkeley-Los Angeles 1983.

27 D. Harvey, Bunt miast. Prawo do miasta i miejska rewolucja, przeł. A. Kowalska i in., Fundacja Bęc Zmiana, Warszawa 2012.

28 M. Mayer, C. Thörn, H. Thörn (eds.), Urban Uprisings: Challenging Neoliberal Urbanism in Europe, Palgrave Macmillan, London 2016. 
litykom miejskim. Jako jeden z wielu przykładów takich działań można wymienić Barcelonę, która skutkiem ,przedawkowania lekarstwa” została bardzo mocno doświadczona procesami gentryfikacji i turystyfikacji. Skutkiem tego, na fali protestów przeciwko tym procesom, urósł w siłę ruch miejski Barcelona en Comú, wprowadzający w 2015 roku 11 (na 41) swoich przedstawicieli do rady miasta, a jego liderka Ada Colau została burmistrzynią katalońskiej metropolii.

\section{Polskie odrodzenie miejskie w warunkach imitacyjnej modernizacji}

Neoliberalny model polityk miejskich trafił w Polsce na bardzo podatny grunt. Polski wzór kulturowy, ukształtowany w procesie długiego trwania, z silnymi narracjami antyurbanistycznymi, nie stwarzał większych podstaw dla myślenia o mieście jako wspólnocie. Dodatkowo antyobywatelska polityka PRL-u przyczyniała się do tworzenia socjologicznej próżni ${ }^{29}$, w ramach której poza strefą prywatną ograniczaną do wąsko pojmowanej rodziny, i narodem rozumianym jako wspólnota wyobrażeniowa rozpościerała się strefa pustki. Skutkiem tych zależności tożsamość miasta - kluczowy zasób dla kształtowania się ducha wspólnotowego - nie mogła się w pełni rozwinąć. Jeszcze w początkach XXI wieku Ewa Rewers, analizując kwestię tożsamości polskich miast, pisała, że „polskie miasta pod tym względem są upośledzone, ich miejskość nierozpoznana, świadomość miasta lekceważona" ${ }^{\text {30 }}$. Deficyt miejskości niejako legitymizował opisywane powyżej procesy prywatyzacji miasta, która w dyskursie publicznym przedstawiana była jako coś oczywistego, wręcz konieczność dziejowa, następująca po okresie realnego socjalizmu.

Przyjęcie takiego modelu polityk miejskich skutkował wieloma dysfunkcjami, które pomimo zaistnienia dogodnych warunków dla rozwoju miejskości ograniczały jej rozwój. Chaos przestrzenny, będący wynikiem de facto oddania planowania przestrzennego w ręce deweloperów, rozwój osiedli grodzonych oraz chaotycznej suburbanizacji (urban sprawl) - wszystko to sprawiało, że miejskość nie mogła się w pełni rozwinąć. Jedną z konsekwencji takiego modelu rozwoju był brak obywatelskiego zaangażowania w sprawy miasta, społecznej kontroli nad politykami miejskimi, co w sposób oczywisty przekładało się na kondycję lokalnej demokracji. Analizując narastający kryzys europejskiej demokracji, Tony Judt zwracał uwagę na wątpliwą rolę osiedli grodzonych: „Chcemy w nich mieszkać, ponieważ odgradzamy się w ten sposób od innych (którym powiodło się gorzej niż nam), a jednocześnie zapewniamy

29 S. Nowak, System wartości społeczeństwa polskiego, „Studia Socjologiczne” 1979, nr 4, s. 155-173.

30 E. Rewers, Wprowadzenie, w: eadem (red.), Miasto w sztuce - sztuka miasta, Universitas, Kraków 2010, s. 14. 
sobie i naszej rodzinie pewne przywileje. Taka patologia stanowi największe zagrożenie dla zdrowia każdej demokracji"31.

Opisywane problemy były o tyle istotne dla rozwoju miejskości w Polsce, że odnosiły się do kluczowych grup mających wpływ na charakter demokracji lokalnej i rozwój miast. Kwestia ta dotyczyła przede wszystkim rodzącej się rodzimej klasy średniej oraz decydentów odpowiadających za polityki publiczne w miastach. Obie te grupy zostały wyjątkowo silnie ,ukąszone” przez ideologię neoliberalną, co miało istotny wpływ na rzeczywistość polskich miast. W pewnym uproszeniu sytuację tę można przedstawić za pomocą metafory, w ramach której miasto opisywane jest na wzór firmy. Metafora ta, będąca symbolem neoliberalnego modelu polityk miejskich, tworzyła przekonanie o tym, że zarówno zarządzanie miastem, jak i jego użytkowanie powinny być dostosowane do takich samych wymogów i zasad, jakie stosuje się w przypadku przedsiębiorstw. Tendencje takie, jeszcze dekadę temu niemal powszechne, niosły w sobie wiele negatywnych konsekwencji dla rozwoju miast, a zwłaszcza ich tożsamości opartej na idei miasta jako wspólnoty. Z jednej strony przekonanie o tym, że miastem powinno się zarządzać zgodnie z takimi samymi zasadami, jakie stosowane są w przypadku przedsiębiorstw działających na wolnym rynku, skutkowało traktowaniem przestrzeni miasta w czysto merkantylny sposób. Z perspektywy bilansów kwartalnych przestrzenie publiczne i miejsca wspólne były deficytowe, tym bardziej zatem pojawiał się argument za ich prywatyzacją. Z drugiej strony przekonanie o tym, iż można z miasta ,wyjść/wyjechać” do „,domu” (na przedmieścia, osiedle grodzone), tak jak to się robi w przypadku firmy, sprawiało, iż przestrzenie publiczne i miejsca wspólne postrzegane były jako zupełnie nieistotny element miasta, generujący jedynie koszty utrzymania.

\section{Przełamywanie dogmatu. Ruchy miejskie}

Przełamanie neoliberalnego dogmatu w kontekście rodzimych polityk miejskich dokonało się w dużej mierze dzięki działalności ruchów miejskich ${ }^{32}$. Polskie ruchy miejskie przy całej swojej złożoności, powstawały w reakcji na opisywane powyżej problemy, które dodatkowo stymulowane były boomem inwestycyjnym wywołanym akcesją do Unii Europejskiej. Autorzy Anty-bezradnika przestrzennego, wywodzący się z poznańskiego środowiska ruchów miejskich, o genezie tego zjawiska pisali w sposób następujący:

ruchy miejskie w całej swojej złożoności pojawiły się właśnie jako reakcja na „boom” inwestycyjny ostatniej dekady - a o ich zróżnicowaniu świadczy odmienny stosunek do tego

31 T. Judt, Źle ma się kraj. Rozprawa o naszych współczesnych bolączkach, przeł. P. Lipszyc, Wydawnictwo Czarne, Wołowiec 2011, s. 164.

32 Szczegółową analizę polskich ruchów miejskich na podstawie badań własnych przedstawiam w książce: P. Kubicki, Ruchy miejskie w Polsce, Wydawnictwo Nomos, Kraków 2020, oraz w artykule: P. Kubicki, Ruchy miejskie w Polsce. Dekada doświadczeń, „Studia Socjologiczne” 2019, nr 3 (234), s. 5-30. 
fenomenu. Polskie ruchy miejskie pojawiły się na tej fali inwestycyjnej, która naruszyła tkankę miejską i, co za tym idzie, naruszyła także relacje społeczne, które w tej tkance były zawarte ${ }^{33}$.

Środowiska współtworzące ruchy miejskie były bardzo zróżnicowane: część wywodziła się z tradycji anarchistycznych ${ }^{34}$, inne miały charakter (nowo)mieszczań$\mathrm{ski}^{35}$. Niemniej jednak, pomimo wielu istotnych różnic, polskie ruchy miejskie potrafiły wypracować wspólną narrację zawartą w Tezach Miejskich ${ }^{36}$, która w dużej mierze oparta była na idei miasta jako dobra wspólnego. Jeden z badaczy polskich ruchów miejskich, Przemysław Pluciński, pisał, że:

najsilniejszym bodaj kryterium identyfikacji MRS [miejskich ruchów społecznych - przyp. P.K.], pozwalającym traktować je na gruncie socjologicznych teorii ruchów społecznych jako odrębny fenomen, pozostaje względnie spójny kontekst ideowy, do którego się odwołują. Idzie przede wszystkim o idee prawa do miasta, demokracji miejskiej (urban democracy) oraz niekiedy sprawiedliwości przestrzennej (spatial justice). (...) To właśnie one, przede wszystkim ich historycznie określona zmienność oraz praktyki interpretacyjne wytwarzają MRS jako relatywnie jednolity, z całym wewnętrznym zróżnicowaniem, podmiot miejskiej zmiany i hybrydową tożsamość polityczną ruchów, przez którą rozumiem procesy autodefinicyjne polegające na budowaniu wewnętrznej spójności, konstruowaniu ,ideologicznego my” rozmaitych frakcji MRS $^{37}$.

Dzięki wypracowaniu własnej narracji ruchy miejskie mogły wpływać na dyskurs publiczny w miastach, choć na taką pozycję musiały pracować latami. Ruchy społeczne zawsze powstają na marginesie ustalonego porządku publicznego i dominującego dyskursu, a ich działalność najczęściej polega na kontestowaniu zastanego porządku społecznego i utartych przekonań. Skutkiem tego, w pierwszej fazie formowania się, są one lekceważone i poddawane silnym procesom stereotypizacji. Badacze ruchów społecznych Donatella della Porta i Mario Diani pisali o takiej sytuacji w sposób następujący: „grupy mające władzę opisują działaczy poszczególnych ruchów, zwłaszcza na początkowych etapach mobilizacji, jako ludzi zdeprawowanych, słabych moralnie i nieuczciwych, którzy nie chcą zaakceptować podstawowych wartości danego społeczeństwa"38. W przypadku polskich ruchów miejskich stereotypy, poprzez które je postrzegano, odnosiły się do dwóch zasadniczych

33 L. Mergler, K. Pobłocki, M. Wudarski, Anty-bezradnik przestrzenny-prawo do miasta w działaniu, Res Publica Nowa, Warszawa 2013, s. 22.

34 P. Pluciński, M. Nowak, E pluribus unum? Źródła i specyfika ruchów miejskich we wspótczesnej Polsce, „Przegląd Socjologiczny” 2017, nr 3, s. 115-135.

35 P. Kubicki, Nowi mieszczanie - nowi aktorzy na miejskiej scenie, „Przegląd Socjologiczny” 2011, nr 2-3, s. 135-161.

36 Szczegóły na stronie Kongresu Ruchów Miejskich: https://kongresruchowmiejskich.pl/tezy-miejskiespis (dostęp: 1.06.2020).

37 P. Pluciński, Im lepiej, tym gorzej albo widmo kryzysu miejskich ruchów społecznych?, „Ruch Prawniczy, Ekonomiczny i Socjologiczny" 2015, z. 1, s. 415-416.

38 D. della Porta, M. Diani, Ruchy społeczne. Wprowadzenie, przeł. A. Sadza, Wydawnictwo Uniwersytetu Jagiellońskiego, Kraków 2009, s. 117. 
wątków. Z jednej strony aktywiści i aktywistki miejskie prezentowani byli jako tzw. pieniacze, osoby stojące na drodze modernizacji polskich miast, z drugiej zaś jako swoista młodzieżowa subkultura, której styl życia sprowadza się do jeżdżenia na holenderskich rowerach i popijania kawy latte w modnych klubokawiarniach. W obu przypadkach przebijało wyraźne lekceważenie ruchów miejskich przez wszystkich tych, którzy zamknięci w dyskursie TINA (There is no alternative) postrzegali opisywane dysfunkcje rozwoju miasta oparte na modelu neoliberalnym jako nieuchronne koszty modernizacji i ,doganiania” Zachodu.

Ruchom miejskim udało się jednak przełamać „błędne uznanie”, czyli mechanizm społecznej dominacji, w ramach którego grupy posiadające władzę mają też potencjał narzucania piętnujących tożsamości grupom podporządkowanym ich wła$\mathrm{dzy}^{39}$. Na tę sytuację wpływ miało wiele czynników. Z jednej strony ruchy miejskie odnosiły coraz większe sukcesy na polu politycznym, pokazując, że są podmiotem zdolnym do kreowania lokalnego pola politycznego. W ramach przykładu można wymienić kilka takich działań, jak: zatrzymanie w drodze referendum organizacji Zimowych Igrzysk Olimpijskich 2020 w Krakowie, opublikowanie „Mapy warszawskiej reprywatyzacji”, która w istotny sposób wpłynęła na scenę polityczną stolicy kraju, a także sukcesy w wyborach samorządowych w 2014 roku. Dodatkowo przez całą ostatnią dekadę postępowała integracja i profesjonalizacja ruchów miejskich. Kluczową rolę w tym przypadku odegrał powstały w 2011 roku Kongres Ruchów Miejskich. Początkowo KRM funkcjonował jako nieformalna struktura sieciowa integrująca ruchy miejskie z różnych miast. Od 2017 roku KRM działa już jako formalne stowarzyszenie, co przełożyło się na większy dynamizm i profesjonalizm działań dzięki usprawnieniu komunikacji wewnętrznej ruchów miejskich. Szczególnie istotne było jednak wypracowanie spójnej polityki komunikacyjnej na zewnątrz, dzięki czemu ruchy miejski mogły kształtować spójny wizerunek publiczny, co przyczyniało się do przełamywanie negatywnych stereotypów.

Dzięki opisywanym procesom ruchy miejskie, mimo że stosunkowo nieliczne, zyskały znaczny wpływ na kształtowanie dyskursu publicznego w miastach. Jak przekonywał Alain Touraine, to w sferze języka dokonują się wybory intelektualne i wykuwają się warunki komunikacji, które narzucają reguły gry, przyznają tym, a nie innym przywilej bycia słuchanym ${ }^{40}$. Ruchy miejskie zaczęły być coraz uważniej słuchane, dzięki czemu mogły wpływać na zmianę dominującej narracji, stopniowe odchodzenie od dogmatów ideologii neoliberalnej w kierunku myślenia o mieście jako wspólnocie. Tendencje te dało się już zaobserwować od pewnego czasu, na co zwracała uwagę między innymi Marta Smagacz-Poziemska, pisząc, że:

o ile jeszcze kilkanaście lat temu w Polsce z milczącą aprobatą mieszkańców spotykało się mówienie o mieście jak o przedsiębiorstwie (z wolnorynkową misją, strukturą, finansami), o tyle

39 Ch. Taylor, Źródła podmiotowości. Narodziny tożsamości nowoczesnej, przeł. M. Gruszczyński i in., Państwowe Wydawnictwo Naukowe, Warszawa 2001.

40 A. Touraine, Myśleć inaczej, przeł. M. Byliniak, Państwowy Instytut Wydawniczy, Warszawa 2011. 
dziś taki język - i zawarta w nim społeczna ideologia - spotyka się ze sprzeciwem. Społecznymi rzecznikami, którzy na poziomie języka naturalnego wpływają na rozumienie roli miasta, są przede wszystkim uczestnicy ruchów miejskich - publicznie rozprawiając się z wolnorynkowym dyskursem o mieście i upowszechniając alternatywną narrację o mieście uspołecznionym: mieście nie wielkich eventów i stadionów, ale podstawowej i dostępnej dla wszystkich infrastruktury społecznej ${ }^{41}$.

Kwestie te nabrały szczególnego znaczenia w kontekście pandemii COVID-19. Trudno obecnie stawiać jakieś daleko idące wnioski co do zmian, jakie pandemia wywoła w miastach. Jedna kwestia wydaje się dalece prawdopodobna, a mianowicie powrót idei miasta jako dobra wspólnego i ostateczne odchodzenie od neoliberalnych polityk miejskich. Dotychczasowe doświadczenia sytuacji pandemii pokazały, jak ważną rolę odgrywa duch wspólnoty i siła lokalnych tożsamości. W tej nowej sytuacji narracja ruchów miejskich może stać się ważnym impulsem inicjującym głęboką zmianę społeczno-kulturową.

\section{Posumowanie. Powrót miejskiego communitas}

Podsumowując, chciałbym odnieść się do tego, czy i w jaki sposób idea miasta jako dobra wspólnego wpłynie na rzeczywistość polskich miast po pandemii COVID-19, choć ze zrozumiałych względów nie sposób obecnie wysnuwać daleko idących wniosków. W tym celu na obecną sytuację chciałbym spojrzeć przez pryzmat koncepcji zmiany kulturowej opisanej przez Victora Turnera. Dotychczasowe doświadczenia pandemii pokazały, że pomimo obowiązującego social distancing w miastach rozwinął się duch wspólnoty i solidarności, co często wskazywane jest jako jeden z najbardziej pozytywnych efektów pandemii. Idea miasta jako wspólnoty, jak już wiemy, rozwijała się w Polsce jedynie w wąskich niszach, na peryferiach głównego dyskursu. Turner takie nisze definiował jako sfery communitas, swoiste szczeliny w systemie, w których dopuszczalne są eksperymenty dotyczące norm i wartości, gdzie presja zasadniczych struktur jest słabsza, a wszelkie odstępstwa od głównego nurtu traktowane są jako niegroźne dla struktury zasadniczej ,zabawy”. W podobny sposób można opisać funkcjonowanie polskich ruchów miejskich, których działalność i głoszone przez nie postulaty długo traktowane były w kategorii owych ,zabaw". W sytuacji głębokiej zmiany kulturowej, a za taką można uznać czas pandemii i jej następstwa, sytuacja ulega jednak gruntownemu przewartościowaniu, co brytyjski antropolog opisywał w następujący sposób:

kiedy badamy instytucje kultury, musimy przyglądać się lukom, niszom, przerwom, a na peryferiach struktury społecznej nawet znajdować mimowolne kulturowe uznanie tego pierwotnego trybu relacji międzyludzkich. $Z$ drugiej strony, w czasach gwałtownej i trwałej zmiany

${ }^{41}$ M. Smagacz-Poziemska, Czy miasto jest niepotrzebne? (Nowe) przestrzenie życiowe mlodych mieszkańców miast, Wydawnictwo Naukowe Scholar, Warszawa 2015, s. 23. 
społecznej właśnie communitas często okazuje się centralne, a struktura tworzy ważniackie, normalne peryferia ${ }^{42}$.

To właśnie w sferach communitas kiełkowały idee i wartości miejskie odnoszące się do ducha wspólnoty, podczas gdy w głównym nurcie dominował dyskurs antyurbanistyczny i neoliberalny. Wiele wskazuje na to, że neoliberalne dogmaty, które dotychczas wyznaczały ramy dla polityk miejskich, stawać się będą „,ważniackimi peryferiami”. Jednym z przykładów może być głęboki kryzys na rynku turystyki miejskiej, której przemiany stymulowane turbokapitalizmem prowadziły do utowarowienia miasta, traktowania go jako produktu na sprzedaż. Bolesne doświadczenia związane z kryzysem tej branży wymuszają na decydentach istotne korekty w dotychczasowych politykach, dostosowanie turystyki także do potrzeb i oczekiwań wspólnot lokalnych.

Pandemia przyspieszyła procesy obserwowane już od pewnego czasu. W okresie poakcesyjnym postępował intensywny proces europeizacji polskiego społeczeństwa w wymiarze oddolnym (bottom-up). Dotyczył on głównie nowego mieszczaństwa, które coraz bardziej zanurzone w wartościach europejskich, postrzegało miasto w kategoriach dobra wspólnego, a nie sumy prywatnych własności. Ruchy miejskie głoszące takie postulaty zyskiwały zatem coraz więcej zwolenników, dzięki czemu można było obserwować proces, który badacze ruchów społecznych nazywają zgrywaniem ram interpretacyjnych. W ramach tego procesu „Podstawowym warunkiem powodzenia jest to, by między działaniami ruchów a populacjami które chcą oni pobudzić do działania, doszło do dostosowania ram. (...) Mamy z nim do czynienia wtedy, gdy opisy symbolicznie tworzone przez działaczy ruchów uwzględniają obecne w społeczeństwie interpretacje rzeczywistości, na które w innej sytuacji nie zwrócono by uwagi" ${ }^{43}$. Postulaty ruchów miejskich, zyskujące coraz większe poparcie społeczne, zaczęły sukcesywnie wpływać również na polityki miejskie, czego dobrym przykładem mogą być ostanie (2018) wybory samorządowe, kiedy to większość kandydatów i kandydatek mówiła już językiem ruchów miejskich. Czas pandemii tylko utwierdza w przekonaniu, że miasta bez tożsamości i ducha wspólnoty nie wykazują się odpornością w sytuacji zagrożenia, okazało się też, że model gospodarki miejskiej opartej na wspólnocie, dzięki wsparciu wiernych klientów, miał dużo większe szanse na przetrwanie kryzysu pandemii niż ten, który hołdował neoliberalnym zasadom. Na czas pandemii można zatem spojrzeć jak na sytuację zmiany kulturowej, w ramach której na znaczeniu zyskiwać będzie idea miasta jako wspólnoty.

\footnotetext{
42 V. Turner, Gry społeczne, pola i metafory. Symboliczne działanie w społeczeństwie, przeł. W. Usakiewicz, Wydawnictwo Uniwersytetu Jagiellońskiego, Kraków 2005, s. 225.

43 D. della Porta, M. Diani, op. cit., s. 90.
} 


\section{Bibliografia}

Barber B., Gdyby burmistrzowie rządzili światem, przeł. H. Jankowska, K. Makaruk, Wydawnictwo Muza, Warszawa 2014.

Bukowski A., Wspólzarządzanie europejskim miastem - powrót do demokratycznych korzeni? Wnioski z realizacji programu badawczego Demos, w: K. Gorlach, P. Mooney (red.), Dynamika życia społecznego. Współczesne koncepcje ruchów społecznych, Wydawnictwo Naukowe Scholar, Warszawa 2005.

Castells M., Kwestia miejska, przeł. B. Jałowiecki, J. Piątkowski, Państwowe Wydawnictwo Naukowe, Warszawa 1982.

Castells M., The City and the Grassroots: A Cross-cultural Theory of Urban Social Movements, University of California Press, Berkeley-Los Angeles 1983.

Czornik M., Miejskość dóbr wspólnych. Refleksje nad adaptowaniem koncepcji CommonPool Resources, „Rozwój Regionalny i Polityka Regionalna” 2018, nr 43, s. 71-82.

della Porta D., Diani M., Ruchy społeczne. Wprowadzenie, przeł. A. Sadza, Wydawnictwo Uniwersytetu Jagiellońskiego, Kraków 2009.

Florida R., Narodziny klasy kreatywnej, przeł. T. Krzyżanowski, M. Penkala, Narodowe Centrum Kultury, Warszawa 2010.

Glaeser E., Triumph of the City: How Urban Space Make Us Human, Pan Books, London 2012.

Glass R., London: Aspects of Change, MacGibbon \& Kee, London 1964.

Grabkowska M., Przestrzeń miasta postsocjalistycznego jako dobro wspólne. Przegląd koncepcji teoretycznych, „Prace Geograficzne” 2017, z. 149, s. 33-53, DOI: 10.4467/20833113PG.17.009.6925.

Grzybowski S., Trzynaście miast, czyli antymonie kultury europejskiej, Zakład Narodowy im. Ossolińskich, Wrocław-Warszawa-Kraków 2000.

Hannerz U., Odkrywanie miasta. Antropologia obszarów miejskich, Wydawnictwo Uniwersytetu Jagiellońskiego, Kraków 2006.

Harvey D., Bunt miast. Prawo do miasta i miejska rewolucja, przeł. A. Kowalska i in., Fundacja Bęc Zmiana, Warszawa 2012.

Judt T., Źle ma się kraj. Rozprawa o naszych współczesnych bolaczkach, przeł. P. Lipszyc, Wydawnictwo Czarne, Wołowiec 2011.

Kubicki P., Nowi mieszczanie - nowi aktorzy na miejskiej scenie, „Przegląd Socjologiczny” 2011, nr 2-3, s. 135-161.

Kubicki P., Ruchy miejskie w Polsce, Wydawnictwo Nomos, Kraków 2020.

Kubicki P., Ruchy miejskie w Polsce. Dekada doświadczeń, „Studia Socjologiczne” 2019, nr 3 (234), s. 5-30, DOI: 10.24425/sts.2019.126150.

Kubicki P., Wynajdywanie miejskości. Polska kwestia miejska z perspektywy dtugiego trwania, Wydawnictwo Nomos, Kraków 2016.

Landry Ch., Kreatywne miasto. Zestaw narzędzi dla miejskich innowatorów, Narodowe Centrum Kultury, Warszawa 2014.

Majer A., Odrodzenie miast, Wydawnictwo Naukowe Scholar, Wydawnictwo Uniwersytetu Łódzkiego, Łódź-Warszawa 2014.

Mayer M., Thörn C., Thörn H. (eds.), Urban Uprisings: Challenging Neoliberal Urbanism in Europe, Palgrave Macmillan, London 2016. 
Mergler L., Pobłocki K., Wudarski M., Anty-bezradnik przestrzenny - prawo do miasta $w$ działaniu, Res Publica Nowa, Warszawa 2013.

Murzyn-Kupisz M., Działek J., Artyści w przestrzeni miejskiej Krakowa i Katowic, Universitas, Kraków 2017.

Offe C., Nowe ruchy społeczne. Przekraczanie granic polityki instytucjonalnej, w: P. Sztompka, M. Kucia (red.), Socjologia. Lektury, Wydawnictwo Znak, Kraków 2016.

Orzechowska-Wacławska J., Baskijskie polityki miejskie: konstruowanie nowej symboliki i nowego oblicza Bilbao, „Politeja. Pismo Wydziału Studiów Międzynarodowych i Politycznych UJ" 2014, nr 27, s. 209-227.

Pluciński P., Im lepiej, tym gorzej albo widmo kryzysu miejskich ruchów społecznych?, „Ruch Prawniczy, Ekonomiczny i Socjologiczny" 2015, z. 1, s. 409-423.

Pluciński P., Nowak M., E pluribus unum? Źródła i specyfika ruchów miejskich we współczesnej Polsce, „Przegląd Socjologiczny” 2017, nr 3, s. 115-135.

Rewers E., Wprowadzenie, w: eadem (red.), Miasto w sztuce - sztuka miasta, Universitas, Kraków 2010.

Rybicki P., Społeczeństwo miejskie, Państwowe Wydawnictwo Naukowe, Warszawa 1972.

Samsonowicz H., Życie miasta średniowiecznego, Wydawnictwo Poznańskie, Poznań 2001.

Shorto R., Amsterdam. Historia najbardziej liberalnego miasta na świecie, przeł. W. Jeżewski, Wydawnictwo Magnum, Warszawa 2013.

Smagacz-Poziemska M., Czy miasto jest niepotrzebne? (Nowe) przestrzenie życiowe młodych mieszkańców miast, Wydawnictwo Naukowe Scholar, Warszawa 2015.

Szahaj A., Neoliberalizm, turbokapitalizm, kryzys, Instytut Wydawniczy Książka i Prasa, Warszawa 2017.

Taylor Ch., Źródła podmiotowości. Narodziny tożsamości nowoczesnej, przeł. M. Gruszczyński i in., Państwowe Wydawnictwo Naukowe, Warszawa 2001.

Tönnies F., Wspólnota i stowarzyszenie. Rozprawa o komunizmie i socjalizmie jako empirycznych formach kultury, Państwowe Wydawnictwo Naukowe, Warszawa 1988.

Turner V., Gry społeczne, pola i metafory. Symboliczne działanie w spoleczeństwie, przeł. W. Usakiewicz, Wydawnictwo Uniwersytetu Jagiellońskiego, Kraków 2005.

Touraine A., Myśleć inaczej, przeł. M. Byliniak, Państwowy Instytut Wydawniczy, Warszawa 2011.

Weber M., Gospodarka i społeczeństwo. Zarys socjologii rozumiejącej, przeł. D. Lachowska, Wydawnictwo Naukowe PWN, Warszawa 2002.

Zukin S., The Cultures of Cities, Blackwell, Oxford 1995.

\section{Źródła internetowe}

https://kongresruchowmiejskich.pl/ 